\title{
Key Success Factors for Doing Business in Hot Air Balloon Riding
}

\author{
Bertan, Serkan \\ Pamukkale University, Tourism Management, Denizli, Turkey.
}

Received: 6 January 2020. Revision received: 14 May 2020. Accepted: 17 May 2020.

\begin{abstract}
The presented study analyzes the relation between customer satisfaction with balloon riding experience and related support activities. The field research by the method of the questionnaire survey of the hot balloon ride events participants was conducted in the Pamukkale district of Denizli province in Turkey. The target group of the research consisted of people who came to Pamukkale and who have participated in the balloon riding activity which is a memorable tourism experience. The questionnaire survey of participants was realized right after their balloon ride experience by research volunteers. Collected data were analyzed through reliability, factor, and regression analyses using package software. In the scope of memorable tourism experiences, the highest average value among the effects of the balloon ride experience was identified in case of happiness, followed by satisfaction and spending level. The effects of the balloon ride experience on happiness, satisfaction, and spending level were positively impacted by the support given for the improvement of hot air balloon activities. The variables describing satisfaction, happiness, and spending level were determined as the most important determinants in relation to support given to hot air balloon activities. The results of this study show that balloon businesses have to increase satisfaction, happiness, and spending levels for the customers who participate in the balloon riding experience. In this way, consumers will support hot air balloon activities, thus increasing the demand for hot air balloon experiences.
\end{abstract}

Key Words: Air sports, Balloon Business, Hot Air Balloon Tours, Hot Air Balloon Experience, Hot Air Balloon Activity, Balloon Tourism.

JEL Classification: M10, M30, Z32.

Reference: Bertan, S. (2020). Key Success Factors for Doing Business in Hot Air Balloon Riding. Journal of Tourism and Services, 20(11), 124-131. doi: 10.29036/jots.v11i20.131

\section{Introduction}

There are various characteristics that distinguish many destinations in the world from others. It is quite important to present the different characteristics as different activities with an innovative and creative approach. Another critical point is to enable the visitors discover different experiences themselves by designing and managing activities, thus creating unforgettable experiences through these activities. Unforgettable experiences make natural and cultural characteristics of the destination memorable too. Due to changing competitive conditions in the recent years, attracting more visitors to the destinations is only possible through transforming the activities into memorable experiences.

Experiences are those which preserve local culture, customs and traditions and hand these down to the next generations (Sthapit and Jimenez-Barreto, 2018; Mura \& Kajzar, 2019). However, it is quite challenging to define the concept of tourism experience due to its complexity originating from its versatile nature (Seyfi, et al., 2019). Nevertheless, recent years have seen an increase in the studies dealing with 


\section{JOURNAL OF TOURISM AND SERVICES}

Issue 20, volume 11, ISSN 1804-5650 (Online)

www.jots.cz

tourism experience; these studies assumed that tourist's experience depends on the interaction between destinations, their elements and tourists, they focused on participatory experiences as well as personal and emotional dimensions of experiences, many intercultural comparisons were made and researches were conducted on the determining factors of tourism experiences revolving around how different nationalities exhibit different touristic behaviors (Akkuş, 2017; Vada et al., 2019).

Tourism in Pamukkale destination contributes significantly to the development and economy of the region. Balloon tours started in Pamukkale, which is included in the UNESCO World Heritage List, in 2015. 153,511 people participated in the balloon tour between January and October 2019 (TRT, 2019). The number of visitors who attend the balloon tour in Pamukkale destination is increasing day by day. As a result, balloon tours make it an important attraction center for the destination.

The purpose of this study is to reveal the effects of balloon ride experience and analyze the relation between these effects and support given for the improvement of hot air balloon activities. No other study has been encountered in the literature dealing with the effects of balloon ride experience as an memorable tourism experience and support given for the improvement of hot air balloon activities as a subject.

\section{Literature review}

Researchers define the positive memory of tourism experiences after the activity as an memorable tourism experience (Sthapit and Jimenez-Barreto, 2018). Providing memorable tourism experiences is quite important in order to succeed in the competitive tourism market (Kim, 2014). Because when asked about their holidays, tourists answer first with their memorable experiences (Vada et al., 2019). memorable tourism experiences attract tourists to a particular area, increase visitor numbers in destinations, generate income for both local people and the region, increase motivations of individuals and encourage consumers to participate in tourism activities (Sthapit and Jimenez-Barreto, 2018; Bacik et al., 2019; Krajcik et al., 2019). Since masterfully planned and managed experiences create customer satisfaction, it is important to present visitors with memorable experiences and to research what is required to increase these experiences (Akkuş, 2017; Vada et al., 2019). Satisfying the requirement of customers is the most important issue of the present day economic environment (Krylov, 2019).

There are very few studies in the current tourism literature about the factors related to memorable tourism experiences (Kim et. al., 2012). When memorable tourism experience literature is reviewed, studies are observed to support the relation between memorable tourism experiences and subjective wellbeing and to emphasize the positive effect of tourism experiences on subjective well-being (Vada et al., 2019). The relation between memorable tourism experiences and subjective well-being dimensions was analyzed through structural equation model, subjective well-being was observed to be effected by meaningfulness and hedonism, and it is understood that mediating variables of gender, age and nationality have an important impact on the connection between subjective well-being and memorable tourism experiences (Sthapit and Coudounaris, 2018). Memorable tourism experiences significantly effect spatial attachment and subjective well-being, the frequency of visits have an impact on these relations and destination loyalty increases when the experiences are memorable for tourists (Vada et al., 2019). In light of the information obtained through interviews conducted with twenty participants with the purpose of discovering central elements of unforgettable hospitality experience, it is observed that the participants generally perceive their experiences positively (Sthapit and Jimenez-Barreto, 2018). Researchers in the field have put forth factors of affective cognitive evaluations, feelings, and novel events in order to enable memorable activities (Kim et. al., 2012). Theoretical model of unforgettable cultural tourism experience was analyzed in a study conducted in Paris with 29 tourist through in-depth face to face interviews, and six key factors were determined to effect cultural tourism experiences: significance of the experience, service quality, authenticity, cultural exchange, engagement, culinary attraction (Seyfi, et al., 2019). From 


\section{JOURNAL OF TOURISM AND SERVICES}

Issue 20, volume 11, ISSN 1804-5650 (Online)

www.jots.cz

a data analysis perspective, the constituents of unforgettable food experiences were determined as authenticity, servicescape, local specialities and food attributes, novelty, togetherness and social interaction, and hospitality; and a new model was proposed and tested for the effects of servicescape, novelty seeking, experience co-creation, choice overload and experience intensification in relation to the memorability of these food experiences (Sthapit, et al., 2019). In case of a typical foreign tourist who tries a dish, the positive effect of originality and cultural contrast is supported through perceived experience while product adaptation is said to decrease the perception of originality and cultural contract (Antón, et al., 2019). When authenticity is sought by tourists, originality has a more significant effect on the perception of experience; individuals are less likely to be effected by cultural contract when they fail to adapt to different cultures (Antón, et al., 2019). Studies contribute in the understanding of the grounds of unforgettable tourism experiences, especially in the context of experiences of cultural tourism (Seyfi, et al., 2019). Kim et al., (2012) have created a scale consisting of 7 factors of refreshment, local culture, hedonism, meaningfulness, knowledge, involvement, and novelty with 23 statements in relation to unforgettable tourism experiences in 2012 which supported internal consistency and validity. A scale tool was developed to conceptualize the characteristics of the targets associated with unforgettable tourism experiences, 10 dimensions were determined to effect unforgettable tourism experiences and this dimensional structure of destination characteristics supported internal consistency and validity of the scale (Kim, 2014).

Hypotheses formulated according to this information are as follows:

H1: There is a positive relation between happiness effect of balloon ride experience and support given to hot air balloon activities.

$\mathrm{H} 2$ : There is a positive relation between satisfaction effect of balloon ride experience and support given to hot air balloon activities.

H3: There is a positive relation between spending effect of balloon ride experience and support given to hot air balloon activities.

In recent years, consumers tend towards different tourism activities, especially memorable activities, and as a result the interest towards unforgettable tourism experiences gradually increases. Hot air balloons and paragliding are the leading unforgettable tourism experiences which are increasing in number everyday. Balloon ride is an activity organized to enable watching natural and cultural beauties from a certain height and to live this experience (SHGM, 2019). The present study analyzes the relation between the effects of experience of balloon ride and support given to hot air balloon activities.

\section{Methods}

In the research, firstly, data were collected, then the data obtained were analyzed and evaluated. The questionnaire was used to collect the data. A questionnaire was implemented on the participants of balloon ride in Pamukkale destination in this study conducted to measure the relation between balloon ride experience as an unforgettable tourism experience and support given to improve hot air balloon activities. Firstly, information was given in the questionnaire about the purpose of the study as well as the time required for filling the questionnaire; it was indicated on the questionnaire that the results will be strictly used for scientific purposes, that collected data may be reported as the findings of the study if required and that the researchers appreciated participants' help. Questionnaire prepared for the field study consisted of two parts. First part consisted of 11 statements related to variables associated with the effects of the balloon ride experience as an unforgettable tourism experience and second part included statements related to support given to balloon activities. And the final part of the questionnaire included questions related to demographic variables (gender, education level, marital status, age).

Different scales were used for the variables indicated within the questionnaire prepared to determine the relation between the effects of balloon ride experience as an unforgettable tourism 


\section{JOURNAL OF TOURISM AND SERVICES}

Issue 20, volume 11, ISSN 1804-5650 (Online)

www.jots.cz

experience and support given for improvement of balloon activities. Statements used in the questionnaire prepared in order to identify the effects of unforgettable tourism experiences were adapted from the scales used in the studies of Peterson, et al., (2005); Neal, et. al., (2007); Ryan et al., (2012); Kim et. al., (2012); Chandralal ve Valenzuela, (2015); Yolal ve diğerlerinin (2016); Eusébio, et al., (2018) ve Li, and Wan, (2017). Statements found in the questionnaire which was created through literature review were scored through 5-point likert type scale (1: I strongly disagree, 2: I disagree, 3: I neither agree nor disagree, 4: I agree, 5: I strongly agree).

Target group of the research consists of people who came to Pamukkale and who have participated in the balloon activity as an unforgettable tourism experience. Participants of balloon ride in Pamukkale were identified through random sampling method. In the field study, data were collected through structured questionnaire in face to face interviews according to the schedule of balloon activities. A pilot test was conducted first on 20 people in order to see whether the questions are understandable. The study was conducted between April $8^{\text {th }}$ and September $2^{\text {nd }}$ of 2019 in Pamukkale through face to face interview method. Questionnaires were implemented on the participants after they had participated in balloon tourism in different time intervals as week days and weekends in different months. The purpose of the researcher was explained after the experience of balloon ride and questionnaire was implemented on those who volunteered. A questionnaire was distributed to 450 visitors and answers were received from 218 visitors.

The data collected by the survey were analyzed. Questionnaire received its final form after reviewing the statements as a result of the validity and reliability analyses. Skewness and kurtosis values and Kolmogorov-Smimov test results were analyzed in order to understand whether factors associated with the variables show normal distribution patterns and variables were understood to be normally distributed. Data were analyzed through reliability, factor and regression analyses using statistical package software. Frequency analysis was conducted on demographic findings. Later, factor analysis was conducted in order to determine reliability of data and factors of the variables. Regression analysis was used to test hypotheses in the study.

Table 1. Demographic Findings

\begin{tabular}{|l|l|l|l|}
\hline Gender & $\%$ & Marital Status & $\%$ \\
Female & 42,3 & Married & 41,4 \\
Male & 57,7 & Single & 56,8 \\
\hline Educational Level & & Age & \\
Primary & 4,5 & -25 & 16,2 \\
High Scholl & 17,1 & $26-30$ & 24,3 \\
Associate & 16,2 & $31-35$ & 21,6 \\
Bachelor Degree & 48,6 & $36-40$ & 15,3 \\
Master/PhD & 12,6 & $41-45$ & 13,5 \\
& & $46+$ & 9 \\
\hline
\end{tabular}

Source: own processing

Demographic characteristics of participants were identified according to the data obtained from the visitors who have participated in balloon rides. In terms of gender, majority of the participants were observed to consist of men with $57.7 \%$. In terms of their marital status, majority of the participants of hot air balloon activity were single people. Participants of balloon tours mostly had bachelor degrees. In terms of age, the age groups of 26-30 and 31-35 were observed to participate in hot air balloon ride most.

Factor analysis was conducted to determine the factors creating the effects of balloon ride experience. Two of the statements were removed from the analysis for the following reasons: "I had nice experiences in balloon ride activity" due to the increase in reliability coefficient when removed and 


\section{JOURNAL OF TOURISM AND SERVICES}

Issue 20, volume 11, ISSN 1804-5650 (Online)

www.jots.cz

"Balloon ride experience was rewarding for me in many ways" due to its presence in more than one factor. Remaining statements were taken into account and total variance according to factor analysis results for the effects of balloon ride experience was found to be $0,66497 \%$ and p 0,001 while Barlett Test of Sphericity and Kaiser-Meyer-Olkin sampling value was found to be $=0,926$.

Table 2. Results of Factor Analysis

\begin{tabular}{|c|c|c|c|c|c|}
\hline & 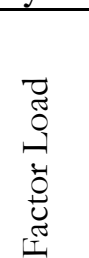 & 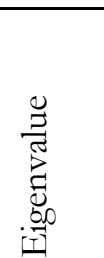 & 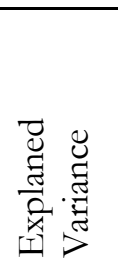 & 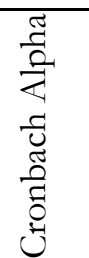 & 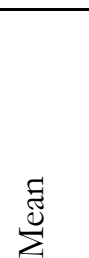 \\
\hline Happiness & & 3,648 & 27,754 & 854 & 4,247 \\
\hline I am happy since balloon ride experience makes me feel better. & 872 & & & & \\
\hline $\begin{array}{l}\text { Balloon ride experience which stimulated my senses within social } \\
\text { interaction was fun. }\end{array}$ &, 797 & & & & \\
\hline $\begin{array}{l}\text { Time flew by in the balloon ride experience as a leisure time } \\
\text { activity. }\end{array}$ &, 789 & & & & \\
\hline I am happy to have participated in the balloon ride experience. & 771 & & & & \\
\hline Satisfaction & & 3,446 & 24,496 & ,827 & 3,942 \\
\hline My skills have developed thanks to the balloon ride experience. & 867 & & & & \\
\hline $\begin{array}{l}\text { I am satisfied with my balloon ride experience since my } \\
\text { expectations were met. }\end{array}$ & ,827 & & & & \\
\hline Balloon ride experience enriched my life. & ,794 & & & & \\
\hline $\begin{array}{l}\text { Balloon ride experience increased my participation in tourism } \\
\text { activities. }\end{array}$ & ,785 & & & & \\
\hline Spending & & 2,725 & 14,247 & ,807 & 3,746 \\
\hline $\begin{array}{l}\text { When I have extra money I would spend it for balloon ride } \\
\text { experience since it provides the opportunity to get to know the } \\
\text { region. }\end{array}$ & ,783 & & & & \\
\hline $\begin{array}{l}\text { I would prefer to spend more money for more } \\
\text { complicated/integrated air sports experience. }\end{array}$ & ,764 & & & & \\
\hline $\begin{array}{l}\text { I would seek more information to participate in balloon ride } \\
\text { experience. }\end{array}$ & ,648 & & & & \\
\hline
\end{tabular}

Total Varyans $=0,66497$ ve p 0,001; Kaiser-Meyer-Olkin $=0,926$

Source: own processing

Taking into account the literature related to the obtained factors, factor weights for each of the items representing each dimension are between 0,771-0,872 for dimension of happiness, between 0,7850,867 for dimension of satisfaction, and between 0,648-783 for dimension of spending level. In scope of unforgettable tourism experiences, the highest average among the effects of the experience of balloon ride was found to belong to happiness, followed by satisfaction and spending level. Factor loads of the statements in all factors are above 0.648. Cronbach alpha coefficients of the factors are above 0,80 .

Regression analysis was used to evaluate the relation between effects of balloon ride experience and support given to hot air balloon activities. The results of the analysis showed that $\mathrm{F}$ value was 21,973 and significant at the level of $\mathrm{p}=, 001$; and since Durbin-Watson test value was between $1,5-2,5$, the result is reflective of the real situation and it is understood to be not random.

Table 3. Results of Regression Analysis

\begin{tabular}{|l|l|l|l|l|}
\hline Variables & Beta & t & Sig t & VIF \\
\hline
\end{tabular}




\section{JOURNAL OF TOURISM AND SERVICES}

Issue 20, volume 11, ISSN 1804-5650 (Online)

www.jots.cz

\begin{tabular}{|c|c|c|c|c|}
\hline (Stables) & 1,795 & 4,483 &, 000 & \\
\hline Satisfaction & 4,482 & 7,240 & 000 & 1,096 \\
\hline Hapiness & 219 & 2,469 & 015 & 1,173 \\
\hline Spending Level &, 116 & 2,103 &, 038 & 1,189 \\
\hline \multicolumn{2}{|l|}{ Multiple Regression $=, 617$} & R Square $=381$ & \multicolumn{2}{|c|}{$p=0.001$} \\
\hline Adjusted R Square $=, 364$ & \multicolumn{2}{|c|}{ Durbin-Watson: 1,717 } & $\mathrm{F}=$ & \\
\hline
\end{tabular}

Source: own processing

The relation coefficient between the variables of visitor satisfaction, happiness and spending levels of balloon ride experiences as an unforgettable tourism experience and support given for improving hot air balloon activities is found to be 0,381. According to this finding, variables of satisfaction, happiness and spending level have an effect on the support given for improvement of hot air balloon activities and there is a cause and effect relation.

As the levels of visitor satisfaction, happiness and spending of the balloon ride experiences as an unforgettable tourism experience increase, the support given for improvement of hot air balloon activities also increases. As these effects decrease, the support given for improvement of hot air balloon tours will also decrease. There is a positive relation between the effects of satisfaction, happiness and spending level of balloon ride experience and support given for the improvement of hot air balloon activities. The variables that explain support given for improvement of hot air balloon activities the best have been determined to be satisfaction $(b=, 482 ; t=7,240 ; p=, 000)$, happiness $(b=, 219 ; t=2,469 ; p=, 015)$, and spending level $(b=, 116 ; t=2,103 ; p=, 038)$, respectively. According to these results, all hypotheses are supported.

\section{Discussion}

This study is quite significant in that this is the first time that the relation between the effects of balloon ride experience and support given for hot air balloon activities is analyzed. Therefore, it is expected to contribute in the literature significantly.

This study was carried out only on people participating in balloon tours in Pamukkale destination due to time limitation. Different regions, especially Cappadocia destination can be compared. The effects of balloon tourism experience on consumer behavior and whether it leads people to travel can be examined in later studies.

Today, it is possible to present unforgettable tourism experiences by making a difference in order to be competitive. In Pamukkale destination, balloon ride offers an unforgettable experience that is not in many parts of the world. Thanks to this unforgettable experience, more tourists visit Pamukkale destination. Natural and cultural riches turn into an unforgettable experience with balloon tourism. In this way, a serious increase in the duration of stay and the number of visitors is provided. The most important elements that people keep in mind during their holidays are unforgettable tourism experiences. Balloon ride over Hierapolis ancient city and natural wonder travertines offers unforgettable tourism experience. In this way, the income from tourism is increasing. Therefore, residents and tourism enterprises should support the development of balloon tourism.

\section{Conclusion}

The results of the study show that the effects of balloon ride experiences as an unforgettable tourism experience emerge on three main dimensions. The significance levels of dimensions show that 


\section{JOURNAL OF TOURISM AND SERVICES}

Issue 20, volume 11, ISSN 1804-5650 (Online)

www.jots.cz

satisfaction and happiness come first and spending level follows these dimensions. In scope of unforgettable tourism experiences, this shows that there is a relation between the effects of balloon ride experience and support given for improvement of hot air balloon activity. When the results are assessed in general terms, balloon ride experiences are observed to have effects on the levels of visitor happiness, satisfaction and spending level. The variables which explain the support given to hot air balloon activities the best were determined to be satisfaction, happiness and spending level, respectively. A positive relation was determined between the effects of visitor happiness, satisfaction and spending level and support given to hot air balloon activities.

To support hot air balloon activities which are increasing in number everyday, it is important to take the effects of balloon ride experiences into account and to do research in line with these. Support given for improvement of hot air balloon activities increases as the levels of satisfaction, happiness and spending levels associated with balloon ride experiences increase. Therefore, effects of balloon ride experiences on satisfaction, happiness and spending levels should be increased in order to increase support given for balloon ride activities. Balloon business managers should encourage increase in the spending amounts by enabling happiness and satisfaction for the participants of balloon ride experience.

\section{References}

1. Akkuş, G. (2017). Kış Turizmi Destinasyonunda Yaşanan Unutulmaz Turizm Deneyimleri: Kültürlerarası Karş1laştırma. Seyahat ve Otel Işletmeciliŭi Dergisi, 14(3), 223-236.

2. Antón, C., Camarero, C., Laguna, M., \& Buhalis, D. (2019). Impacts of authenticity, degree of adaptation and cultural contrast on travellers' memorable gastronomy experiences. Journal of Hospitality Marketing \& Management, 1-22.

3. Bacik, R., Kmeco, L., Richard, F., Olearova, M., \& Rigelsky, M. (2019). Marketing Instrument of Improving Hotel Management Service: Evidence of Visegrad Group Countries. Marketing and Management of Innovations, 208-220. https:// doi.org/10.21272/mmi.2019.1-17

4. Chandralal, L., \& Valenzuela, F. R. (2015). Memorable tourism experiences: Scale development. Contemporary Management Research, 11(3).

5. Eusébio, C., Vieira, A. L., \& Lima, S. (2018). Place attachment, host-tourist interactions, and residents' attitudes towards tourism development: the case of Boa Vista Island in Cape Verde. Journal of Sustainable Tourism, 26(6), 890-909.

6. Kim, J. H., Ritchie, J. B., \& McCormick, B. (2012). Development of a scale to measure memorable tourism experiences. Journal of Travel Research, 51(1), 12-25.

7. Kim, J. H. (2014). The antecedents of memorable tourism experiences: The development of a scale to measure the destination attributes associated with memorable experiences. Tourism management, 44, 34-45.

8. Krajcik, V. (2019). Innovative sharing economy's business models in tourism: case of Airbnb in Prague. Marketing and Management of Innovations, 2, 108-117. https://doi.org/10.21272/mmi.2019.2-10

9. Krylov, S. (2019). Strategic customer analysis based on balanced scorecard. Ekonomickomanazerske spektrum, 13(1), 12-25.

10. Li, X., \& Wan, Y. K. P. (2017). Residents' support for festivals: Integration of emotional solidarity. Journal of Sustainable Tourism, 25(4), 517-535.

11. Mura, L., \& Kajzar, P. (2019). Small Businesses in Cultural Tourism in a Central European Country. Journal of Tourism and Services, 10 (19), 40-54. doi:10.29036/jots.v10i19.110

12. Neal, J. D., Uysal, M., \& Sirgy, M. J. (2007). The effect of tourism services on travelers' quality of life. Journal of Travel Research, 46(2), 154-163. 


\section{JOURNAL OF TOURISM AND SERVICES}

Issue 20, volume 11, ISSN 1804-5650 (Online)

www.jots.cz

13. Peterson, C., Park, N., \& Seligman, M. E. (2005). Orientations to happiness and life satisfaction: The full life versus the empty life. Journal of happiness studies, 6(1), 25-41.

14. Ryan T. Howell , Paulina Pchelin \& Ravi Iyer (2012) The preference for experiences over possessions: Measurement and construct validation of the Experiential Buying Tendency Scale, The Journal of Positive Psychology, 7:1, 57-71, DOI: 10.1080/17439760.2011.626791

15. Seyfi, S., Hall, C. M., \& Rasoolimanesh, S. M. (2019). Exploring memorable cultural tourism experiences. Journal of Heritage Tourism, 1-17.

16. SHGM: Sivil Havacilık Genel Müdürlüğü http://web.shgm.gov.tr/, (Access: 02.09.2019).

17. Sthapit, E. (2017). Exploring tourists' memorable food experiences: A study of visitors to Santa's official hometown. Anatolia, 28(3), 404-421.

18. Sthapit, E., \& Coudounaris, D. N. (2018). Memorable tourism experiences: Antecedents and outcomes. Scandinavian Journal of Hospitality and Tourism, 18(1), 72-94.

19. Sthapit, E., \& Jiménez-Barreto, J. (2018). Exploring tourists' memorable hospitality experiences: An Airbnb perspective. Tourism Management Perspectives, 28, 83-92.

20. Sthapit, E., Coudounaris, D. N., \& Björk, P. (2019). Extending the memorable tourism experience construct: an investigation of memories of local food experiences. Scandinavian Journal of Hospitality and Tourism, 1-21.

21. TRT, 2019. https://www.trthaber.com/foto-galeri/pamukkalede-balonlar-153-bin-kisiyiucurdu/22893.html, (Access: 02.09.2019).

22. Vada, S., Prentice, C., \& Hsiao, A. (2019). The influence of tourism experience and well-being on place attachment. Journal of Retailing and Consumer Services, 47, 322-330.

23. Yolal, M., Gursoy, D., Uysal, M., Kim, H. L., \& Karacaoğlu, S. (2016). Impacts of festivals and events on residents' well-being. Annals of Tourism Research, 61, 1-18.

\section{Brief description of Author/Authors:}

\section{Assoc. Prof. Dr. Serkan BERTAN, PhD.}

Pamukkale University, Faculty of Tourism, Tourism Management, Pamukkale Universitesi, Turizm Fakültesi, Kınıkl1, 20020, Denizli, Turkey, Address, Country, http://www.pau.edu.tr/sbertan/tr, serkanbertan@yahoo.com.

Dr. Serkan's research is to cover tourism, hospitality, management, technology, and management information systems. While he is finishing up his tourism vocational high school and Bachelor's Degree in Tourism Management and Education, Dr. Serkan gained professional experience as an intern at several departments in hotels. He also has a High School Education Licence and served as a high school teacher at Ankara Dogantepe Multi-department High School and Izmir Karsiyaka Gumuspala Commercial High School. After working as a Research Assistant at the Pamukkale University, He attended the PhD Program at Dokuz Eylul University in 2002 and completed his PhD studies within four years. After his Ph.D. degree, he joined Pamukkale University at the Department of Tourism and Hotel Management. In 2009 Dr. Serkan was invited as a fellow researcher to the Department of Hotel, Restaurant and Tourism Management University of South Carolina for his Post Ph.D. Studies. He is Assoc. Prof. Dr., Faculty of Tourism, Pamukkale University at Denizli, Turkey. 